\title{
Apilanurmen apilapitoisuuden säätely kylvöä jaksottamalla
}

\author{
Arja Nykänen ${ }^{1)}$, Hanna Avikainen ${ }^{1)}$, Lauri Jauhiainen ${ }^{2)}$, Petri Leinonen ${ }^{3)}$ ja Päivi Nykänen-Kurki ${ }^{4)}$ \\ ${ }^{1)}$ MTT, Ympäristöntutkimus, Ekologinen tuotanto, 51900 Juva, etunimi.sukunimi@mtt.fi \\ 2)MTT, Tutkimuspalvelut, Tietopalvelu,31600Jokioinen, lauri.jauhiainen@mtt.fi \\ ${ }^{3)}$ Elomestari Oy,51900Juva, petri.leinonen@elomestari.fi \\ 4)MTT, Ympäristöntutkimus, Ekologinen tuotanto, 50600 Mikkeli,paivi.nykanen-kurki@mtt.fi
}

\section{Johdanto}

Suomessa yleisimmin viljelty nurmipalkokasvi seosnurmissa on puna-apila (Trifolium pratense L.). Apilapitoisten nurmien viljelyn suurin ongelma on niiden apilapitoisuuden hallinta sekä lyhyt tuottoikä. Apilapitoisuus muuttuu sekä kasvukauden aikana että nurmen ikääntyessä. Eläinten ruokinnan kannalta apilapitoisuus on usein liian korkea toisessa sadonkorjuussa ja nuorissa nurmissa. Ensimmäisessä sadonkorjuussa ja vanhoissa nurmissa apilapitoisuus taas on usein liian alhainen, kun tarkastellaan nurmen sadontuottoa ja esikasviarvoa nurmen jälkeiselle kasville. Lannoittamattoman apilapitoisen nurmen apilapitoisuus on suoraan verrannollinen nurmen sadon määrään (Kornher 1977).

Euroopassa valkoapilan täydennyskylvö nurmen pintaan on yleinen tapa parantaa laidunrehun laatua (Tiley \& Frame 1988). Tässä tutkimuksessa selvitettiin, voiko puna-apilaseosnurmen apilapitoisuutta säädellä tuotantovuosien aikana kylvämällä osa apilan siemenmäärästä kasvavan nurmen pintaan keväällä. Lisäksi tutkittiin, voiko tällaisella kylvön jaksottamisella pidentää apilapitoisten nurmien tuottoikää ja mikä olisi sopiva siemenmäärä. Uudessa Seelannissa käytetään valkoapilan pintakylvöön siementä, joka on kalkkipilleröity eli kuorrutettu kalkilla ja ympätty Rhizobium-bakteerilla (Jones \& Thomas 1965). Kalkkipilleröinnillä on tarkoitus nostaa maan $\mathrm{pH}$ :ta siemenen välittömässä läheisyydessä typpibakteerien toiminnan parantamiseksi. Tässä tutkimuksessa selvitettiin, onko puna-apilan siemenen kalkkipilleröinnillä vaikutusta nurmien apilapitoisuuteen, sadontuottoon ja typpipitoisuuteen.

\section{Aineisto ja menetelmät}

Kokeet toteutettiin Juvalla kahtena neljävuotisena kenttäkokeena 1999-2002 ja 2001-2004 (koe jatkuu). Koemalli oli osaruutukoemalli, jossa kylvöstrategia (siemenmäärä ja jaksotus) oli pääruutu ja kalkkipilleröinti osaruutu. Kokonaissiemenmäärä oli joko 3 tai $6 \mathrm{~kg} \mathrm{ha}^{-1}$, joka kylvettiin kerralla tai eri tavoin vuosien kesken jaksotettuna (Taulukko 1). Nurmiseoksessa oli puna-apilan lisäksi timoteitä (Phleum pratense L., $10 \mathrm{~kg} \mathrm{ha}^{-1}$ ) ja nurminataa (Festuca pratensis Huds., $5 \mathrm{~kg} \mathrm{ha}^{-1}$ ). Nurmet perustettiin aikainen puitava ohra suojaviljana. Täydennyskylvöt tehtiin pintakylvönä siten, että apilan siemenet kylvettiin nurmen pintaan keväällä mahdollisimman aikaisin ilman minkäänlaista multausta tai harausta. Puolet siemenistä kuorrutettiin kalkilla eli kalkkipilleröitiin ja tarkoituksena nostaa maan $\mathrm{pH}$ :ta siemenen välittömässä läheisyydessä.

Taulukko 1. Puna-apilan kylvömäärät erilaisilla kylvöstrategioilla $\left(\mathrm{kg} \mathrm{ha}^{-1}\right.$ tai $\left.\mathrm{kpl} \mathrm{m}^{-2}\right)$

\begin{tabular}{|c|c|c|c|}
\hline Strategia & Perustamisvuosi & 1. satovuosi & 2. satovuosi \\
\hline 000 & $\mathbf{0}$ & $\mathbf{0}$ & $\mathbf{0}$ \\
\hline 111 & $1 \mathrm{~kg} \mathrm{ha}^{-1}\left(50 \mathrm{kpl} \mathrm{m}^{-2}\right)$ & $1 \mathrm{~kg} \mathrm{ha}^{-1}\left(50 \mathrm{kpl} \mathrm{m}^{-2}\right)$ & $1 \mathrm{~kg} \mathrm{ha}^{-1}\left(50 \mathrm{kpl} \mathrm{m}^{-2}\right)$ \\
\hline 201 & $2 \mathrm{~kg} \mathrm{ha}^{-1}\left(100 \mathrm{kpl} \mathrm{m}^{-2}\right)$ & $\mathbf{0}$ & $1 \mathrm{~kg} \mathrm{ha}^{-1}\left(50 \mathrm{kpl} \mathrm{m}^{-2}\right)$ \\
\hline 222 & $2 \mathrm{~kg} \mathrm{ha}^{-1}\left(100 \mathrm{kpl} \mathrm{m}^{-2}\right)$ & $2 \mathrm{~kg} \mathrm{ha}^{-1}\left(100 \mathrm{kpl} \mathrm{m}^{-2}\right)$ & $2 \mathrm{~kg} \mathrm{ha}^{-1}\left(100 \mathrm{kpl} \mathrm{m}^{-2}\right)$ \\
\hline 300 & $3 \mathrm{~kg} \mathrm{ha}^{-1}\left(150 \mathrm{kpl} \mathrm{m}^{-2}\right)$ & $\mathbf{0}$ & $\mathbf{0}$ \\
\hline 402 & $4 \mathrm{~kg} \mathrm{ha}^{-1}\left(200 \mathrm{kpl} \mathrm{m}^{-2}\right)$ & $\mathbf{0}$ & $2 \mathrm{~kg} \mathrm{ha}^{-1}\left(100 \mathrm{kpl} \mathrm{m}^{-2}\right)$ \\
\hline 600 & $6 \mathrm{~kg} \mathrm{ha}^{-1}\left(300 \mathrm{kpl} \mathrm{m}^{-2}\right)$ & $\mathbf{0}$ & $\mathbf{0}$ \\
\hline
\end{tabular}

Viljavuusanalyysin mukaan peltojen maalaji oli ensimmäisessä kokeessa hietamoreeni ja toisessa hiesumoreeni. Peltojen $\mathrm{pH}_{(\mathrm{CaCl2})}$ vaihteli $6,1-6,4$, orgaanisen aineksen pitoisuus oli 3-6\% ja viljavuus pääravinteiden osalta oli luokissa 'välttävä' - 'tyydyttävä'. Koevuosina kasvukauden lämpötila oli pitkäaikaista keskiarvoa korkeampi muina vuosina paitsi 2001, jolloin heinäkuu oli kuitenkin erittäin lämmin. sademäärät olivat keskimäärin alhaisempia kuin pitkäaikainen keskiarvo ja varsinkin myöhäiskesät olivat kuivia. Kokeissa mitattiin nurmien kuiva-ainesato sekä käsin erotellen sadon apilapitoisuus. Apiloiden ja heinien kokonaistyppipitoisuus määritettiin Kjeldahl-menetelmällä. Lisäksi apilayksilöiden lukumäärä pintaalayksikköä kohti laskettiin kolme kertaa vuodessa (kevät, kesä, syksy). Tulosten tilastollinen merkitsevyys on laskettu SAS Mixed -proseduurilla. 


\section{Tulokset ja niiden tarkastelu}

Apilapitoisten nurmien optimaalinen apilamäärä $\left(30-40 \mathrm{kpl} \mathrm{m}^{-2}\right)$ perustamisvuonna saavutettiin kokeissa parhaiten, kun apilan kylvömääränä käytettiin $2 \mathrm{~kg} \mathrm{ha}^{-1}$ (Taulukot 2 ja 3). Kokeet olivat moreenimailla, joiden maaperäominaisuudet näyttivät olevan hyvät apilanurmien perustamiseen. Myöhempinä vuosina apiloiden lukumäärä laski kuitenkin samalle tasolle perustamisvuoden kylvömäärästä riippumatta. Myös Huokuna (1966) suositteli kylvömääräksi kivennäismaille $2 \mathrm{~kg} /$ ha omien kokeidensa perusteella.

Kylvön jaksottamisella ei ollut selkeää vaikutusta apiloiden määrään nurmessa, vaan suurin vaikutus oli kylvövuonna käytetyllä siemenmäärällä. Ensimmäisessä kokeessa apiloiden määrä laski tasaisesti kokeen edetessä (Taulukko 2). Toisessa kokeessa apilamäärä oli pienimmillään perustamisen jälkeisen talven jälkeen, mutta nousi jälleen kasvukauden ja kokeen edetessä (Taulukko 3). Vaikka täydennyskylvö tehtiin hyvin aikaisin keväällä, ei apiloilla ollut tarpeeksi tilaa kehittyä jo ennestään tiheässä nurmessa. Syynä huonoon tulokseen voi olla myös se, että pintaan kylvetyt siemenet eivät päässeet kontaktiin maan kanssa. Hakkola (1995) on saanut erinomaisia tuloksia puna-apilaseosnurmen paikkauskylvöstä suorakylvökoneella. Erikoista kokeessa 2 on, että apiloiden määrä nousi myös niissä ruuduissa, joihin ei apiloita kylvetty lisää kokeen aikana. Ilmeisesti pellossa on ollut ns. kovia siemeniä, jotka ovat itäneet kokeen kuluessa.

Taulukko 2. Apilan kylvöstrategian vaikutus apiloiden lukumäärään, $\mathrm{kpl} \mathrm{m}^{-2}$, kokeessa 1 eri ajankohtina 1999-2002.

\begin{tabular}{|c|c|c|c|c|c|c|c|c|c|c|}
\hline \multirow[t]{3}{*}{ Kylvöstrategia } & \multicolumn{10}{|c|}{ Apiloiden lukumäärä, $\mathrm{kpl} \mathrm{m}^{-2}$} \\
\hline & \multirow{2}{*}{$\begin{array}{l}1999 \\
\text { Syksy }\end{array}$} & \multirow{2}{*}{$\begin{array}{l}2000 \\
\text { Kevät }\end{array}$} & \multirow[b]{2}{*}{ Kesä } & \multicolumn{2}{|r|}{2001} & \multirow[b]{2}{*}{ Kesä } & \multirow[b]{2}{*}{ Syksy } & \multirow{2}{*}{$\begin{array}{r}2002 \\
\text { Ke- } \\
\text { vät }\end{array}$} & \multirow[b]{2}{*}{ Kesä } & \multirow[b]{2}{*}{ Syksy } \\
\hline & & & & Syksy & $\begin{array}{l}\text { Ke- } \\
\text { vät }\end{array}$ & & & & & \\
\hline 111 & 24.3 & 15.9 & 17.9 & 17.3 & 12.6 & 15.4 & 11.0 & 10.9 & 11.3 & 9.6 \\
\hline 201 & 40.6 & 36.6 & 29.3 & 26.3 & 23.6 & 22.0 & 15.4 & 14.5 & 13.5 & 13.6 \\
\hline 222 & 46.1 & 35.8 & 28.0 & 26.3 & 21.4 & 20.1 & 16.3 & 13.3 & 15.5 & 13.0 \\
\hline 300 & 41.5 & 30.1 & 29.6 & 25.9 & 20.0 & 21.9 & 14.3 & 13.3 & 14.6 & 13.6 \\
\hline 402 & 55.6 & 44.3 & 35.4 & 29.3 & 27.5 & 24.1 & 17.4 & 19.8 & 18.6 & 17.4 \\
\hline 600 & 75.8 & 46.8 & 36.3 & 33.0 & 30.4 & 25.5 & 19.3 & 21.9 & 21.1 & 17.5 \\
\hline & $* * *$ & $* * *$ & $* *$ & $\circ$ & $* * *$ & ** & & ** & ** & * \\
\hline
\end{tabular}

Tilastollinen merkitsevyys eri kylvöstrategioille: ${ }^{o} P<0.10, * P<0.05, * * P<0.01, * * * P<0.001$.

Taulukko 3. Apilan kylvöstrategian vaikutus apiloiden lukumäärään, $\mathrm{kpl} \mathrm{m}^{-2}$, kokeessa 2 eri ajankohtina 2001-2003.

\begin{tabular}{cccccccc}
\hline Kylvöstrategia & \multicolumn{7}{c}{ Apiloiden lukumäärä, kpl m ${ }^{-2}$} \\
& $\begin{array}{c}2001 \\
\text { Syksy }\end{array}$ & $\begin{array}{c}2002 \\
\text { Kevät }\end{array}$ & Kesä & Syksy & $\begin{array}{c}\text { Ke- } \\
\text { vät }\end{array}$ & Kesä & Syksy \\
\hline 111 & 24.5 & 8.5 & 12.4 & 15.6 & 13.5 & 14.5 & 16.5 \\
201 & 28.6 & 10.4 & 16.6 & 18.5 & 13.8 & 15.8 & 18.8 \\
222 & 28.3 & 10.0 & 18.9 & 20.9 & 17.3 & 23.0 & 23.0 \\
300 & 36.3 & 10.8 & 22.8 & 23.6 & 17.0 & 25.8 & 17.0 \\
402 & 45.8 & 12.8 & 28.0 & 26.6 & 25.0 & 31.8 & 30.0 \\
600 & 48.8 & 16.9 & 28.0 & 26.8 & 27.8 & 35.8 & 28.0 \\
& $* * *$ & $* *$ & $* * *$ & $* * *$ & $* * *$ & $* * *$ & $* * *$ \\
\hline
\end{tabular}

Tilastollinen merkitsevyys eri kylvöstrategioille: ${ }^{o} P<0.10, * P<0.05,{ }^{*} P<0.01,{ }^{*} * * P<0.001$.

Apilan kylvön jaksottaminen kolmeen erään vähensi nurmien vuosittaisia kuiva-ainesatoja 80 - $1110 \mathrm{~kg}$ ha $^{-1}$, kun verrattiin samaa kokonaiskylvömäärää keskenään (111 vs. 300 ja 222 vs. 600). Nurmisadot kokeessa 1 olivat $6560-9760$ ja 2 kokeessa $4860-6790 \mathrm{~kg} \mathrm{ha}^{-1} \mathrm{v}^{-1}$ kuiva-ainetta, kun nurmeen oli kylvetty apilaa. Kokeen 2 pienemmät sadot voivat johtua mm. vähäisemmästä apilamäärästä (vrt. taulukot 2 ja 3 ). Kokeessa 1 vuodella oli suurin vaikutus kokonaiskuiva-ainesadontuottoon $(\mathrm{P}<0.001)$. Perustamisvuoden siemenmäärällä oli lähes merkitsevä vaikutus $(\mathrm{P}<0.10)$ toisen niiton sadon määrään. Kylvömäärän nostaminen $3 \mathrm{~kg} \mathrm{ha}^{-1}$ :sta $6 \mathrm{~kg} \mathrm{ha}^{-1}$ :aan lisäsi kuiva-ainesadontuottoa $500 \mathrm{~kg} \mathrm{ha}^{-1}$ kolmen vuoden aikana yhteensä. Kokeessa 2 kylvövuoden siemenmäärän nostaminen lisäsi kokonaiskuiva-ainesadontuottoa tilastollisesti 
merkitsevästi. Käytännön kannalta merkitys ei ole suuri, koska siemenmäärän nostaminen $3 \mathrm{~kg} \mathrm{ha}^{-1}$ :sta 6 $\mathrm{kg} \mathrm{ha}^{-1}$ :aan lisäsi kuiva-ainesadontuottoa $1070 \mathrm{~kg} \mathrm{ha}^{-1} \mathrm{kahden}$ vuoden aikana yhteensä. (Taulukko 4).

Puna-apilan siemenen kylvömäärällä ei ollut käytännön merkitystä sadon apilapitoisuudelle. Tilastollisesti merkittäviä eroja löytyi kuitenkin molempien kokeiden ensimmäisistä niitoista, jolloin kylvöstrategia 111 erosi muista $(\mathrm{P}<0.1$ kokeessa 1 ja $\mathrm{P}<0.01$ kokeessa 2, Taulukko 4). Satojen apilapitoisuudet olivat kokeen 1 ensimmäisissä niitoissa 20-50\% kuiva-aineesta ja toisessa niitossa 40-80\% kuiva-aineesta laskien nurmen vanhetessa. Kokeessa 2 vuoden 2003 ensimmäisen niiton apilapitoisuudet olivat yllättävän korkeita (Taulukko 4).

Taulukko 4. Puna-apilan kylvöstrategian vaikutus nurmisatoihin ja satojen apilapitoisuuteen kokeessa 2 vuosina 2002 ja 2003.

\begin{tabular}{cccccc}
\hline Kylvöstrategia & \multicolumn{3}{c}{ Sato, $\mathrm{kg} \mathrm{ha}^{-1}$ kuiva-ainetta } & \multicolumn{2}{c}{ Apilapitoisuus kuiva-aineena, } \\
& Niitto 1 & Niitto 2 & Yhteensä & Niitto 1 & Niitto 2 \\
& 2002 & 2002 & $2002-2003$ & 2002 & 2002 \\
\hline 111 & 2940 & 2430 & & 8.4 & 63.3 \\
201 & 2380 & 2480 & & 13.5 & 66.7 \\
222 & 2400 & 2650 & & 11.9 & 67.3 \\
300 & 2480 & 2810 & & 9.2 & 70.9 \\
402 & 2530 & 2970 & & 17.0 & 74.0 \\
600 & 2600 & 3100 & & 26.1 & 70.9 \\
& & & & \\
111 & 2003 & 2003 & & 2003 & 2003 \\
201 & 2810 & 2510 & 10680 & 51.1 & 50.2 \\
222 & 2990 & 2670 & 10510 & 63.3 & 58.0 \\
300 & 3130 & 2750 & 10930 & 57.8 & 62.4 \\
402 & 3280 & 2850 & 11420 & 59.4 & 61.6 \\
600 & 3470 & 2910 & 11880 & 65.9 & 68.0 \\
& 3420 & 3370 & 12490 & 69.2 & 61.4 \\
& & $* *$ & $*$ & $* *$ & 0 \\
\hline
\end{tabular}

Tilastollinen merkitsevyys eri kylvöstrategioille: ${ }^{\circ} P<0.10,{ }^{*} P<0.05,{ }^{* *} P<0.01,{ }^{* * *} P<0.001$.

Puna-apilan siemenen kalkkipilleröinti vähensi nurmisatojen apilapitoisuutta 5\%-yksikköä kokeessa 2 ensimmäisen nurmivuoden toisessa niitossa ja toisen nurmivuoden ensimmäisessä niitossa. Kokeessa 1 kalkkipilleröinti puolestaan lisäsi apilapitoisuutta ensimmäisen satovuoden toisessa niitossa. (Taulukko 5).

Peltomaan pH oli molemmissa kokeissa hyvä jo ennen apilan kylvöä, josta syystä kalkkipilleröinti ei vaikuttanut käytännössä nurmen apilapitoisuuteen. Nurmien sadon määrään ei kalkkipilleröinnillä ollut vaikutusta.

Taulukko 5. Puna-apilan kalkkipilleröinnin vaikutus nurmisatojen apilapitoisuuteen (\% kuiva-aineessa) kokeissa 1 ja 2 Juvalla.

\begin{tabular}{lcccccccccc}
\hline Pilleri & Koe 1 & & & \multicolumn{9}{c}{ Koe 2 } & \multicolumn{2}{c}{2003} \\
& 2000 & & 2001 & \multicolumn{2}{c}{2002} & \multicolumn{2}{c}{ 2002 } \\
& Niitto 1 & Nitto 2 & Niitto 1 & Niitto 2 & Niitto 1 & Niitto 2 & Niitto 1 & Niitto 2 & Niitto 1 & Niitto 2 \\
\hline+ & 45.4 & 86.2 & 38.5 & 59.9 & 21.6 & 45.0 & 14.7 & 66.5 & 58.8 & 58.6 \\
- & 48.2 & 77.3 & 37.4 & 59.0 & 26.6 & 44.2 & 14.1 & 71.2 & 63.4 & 61.9 \\
& & $* *$ & & & & & & $* *$ & $*$ & \\
\hline
\end{tabular}

Tilastollinen merkitsevyys eri kylvöstrategioille: ${ }^{\circ} P<0.10,{ }^{*} P<0.05,{ }^{* *} P<0.01,{ }^{* * *} P<0.001$.

Heinien ja apiloiden typpipitoisuuteen vaikutti merkitsevästi $(\mathrm{P}<0.001)$ ainoastaan satovuosi eli siemenen kalkkipilleröinti ja ymppäys ei vaikuttanut typen sidonnan määrään. Syynä lienee maan hyvä pH ja se, että pelloilla on viljelty puna-apilaa jo yli kymmenen vuotta.

\section{Johtopäätökset}

Nurmen sadontuottokyky pysyi hyvänä kolmen satovuoden ajan, kun nurmeen oli kylvetty tarpeeksi apilaa jo nurmen perustamisvaiheessa. Riittävä siemenmäärä näytti olevan 2-4 $\mathrm{kg} \mathrm{ha}^{-1}$. Koepeltojen apilakanta oli hyvä ja hyvin kantavilla mailla pelto ei ollut tiivistynyt. Näissä oloissa apilan kylvön jaksottaminen ei 
lisännyt kolmannen satovuoden apilamäärää. Siemenen kalkkipilleröinnillä ja typpibakteeriymppäyksellä ei myöskään ollut käytännön merkitystä nurmien sadontuottoon, apilapitoisuuteen tai typpipitoisuuteen.

\section{Kirjallisuus}

Hakkola, H. 1995. Nurmen täydennyskylvö onnistuu parhaiten keväällä. Koetoiminta ja käytäntö 52 (19.12.1995): 54-55.

Huokuna, E. 1966. Siementarve nurmia perustettaessa. Nurmien kylvösiemenmäärä. Pellervo. vol. 67:11-12.

Jones, D.G. \& Thomas, S.B. 1965. The use of inoculation and pelleting in the establishment of white clover under mountain conditions. Journal of Applied Bacteriology 29: 430-439.

Kornher, A. 1977. Kväve till klöver-gräsvall med olika typer av rödklöver. Sveriges lantbrukisuniversitet. Institutionen för växtodling. Rapporter och avhandlingar nro 61.25 p.

Tiley, G.E.D. \& Frame, J. 1988. Sward establishment and renovation without ploughing. Proceedings of the 12th General Meeting of the European Grassland Federation, Dublin, Ireland, pp. 199-203. 